\title{
A note on polyvinyl chloride (PVC) pipe traps for sampling vegetation- dwelling frogs in South Africa
}

\author{
Morgan J. Trimble ${ }^{1}$ \& Rudi J. van $\operatorname{Aarde}^{2}$ \\ Conservation Ecology Research Unit, Department of Zoology \& Entomology, University of Pretoria, Private Bag \\ X20, Hatfield Pretoria 0028, South Africa \\ M.J. Trimble: morgantrimble@gmail.com, R.J. van Aarde: rjvaarde@ zoology.up.ac.za
}

Corresponding author: M.J. Trimble, morgantrimble@gmail.com

\section{INTRODUCTION}

Vegetation-dwelling frogs are challenging to sample. They can climb out of traditional traps, and many are furtive (Pittman et al., 2008, Myers et al., 2007). PVC pipe traps, which mimic natural features frogs use for shelter, may provide a useful technique (e.g. Boughton et al., 2000). Pipe trapping has been used to sample treefrogs of the family Hylidae in the United States (e.g. Boughton et al., 2000, Farmer et al., 2009, Liner et al., 2008), but it is increasingly used elsewhere (e.g. Laurencio and Malone, 2009, Ferreira et al., 2012), even for non-Hylids (Coqui Frog Working Group, 2006).

African vegetation-dwelling frog genera, e.g. Leptopelis, Afrixalus, and Hyperolius (see du Preez and Carruthers, 2009, Channing, 2001), may be attracted to artificial refugia of PVC pipe traps. If so, pipe trapping would augment sampling techniques for African anurans, which are little studied (Trimble and Van Aarde, 2010, Trimble and van Aarde, 2012) despite 
conservation needs (Measey, 2011), and could facilitate sampling outside the breeding season, reduce observer and detection bias (see Willson and Gibbons, 2010, Bailey et al., 2004), and allow fundamental and applied ecological studies, e.g. habitat selection (e.g. Pittman et al., 2008, Johnson et al., 2007), migration/dispersal (e.g. Johnson, 2005), and management effects (e.g. Muenz et al., 2006, Rice et al., 2011). In this preliminary assessment, we provide the first evidence that it is possible to capture African frogs in PVC pipe traps in the field. However, capture success was low, so we encourage more research on alternate trap designs and in other habitats.

\section{METHODS}

Our study was conducted in the South African coastal forest within $2.3 \mathrm{~km}$ of the east coast, along a $25 \mathrm{~km}$ section between the Umlalazi River and Richards Bay Harbour. The area harbours a high species richness and concentration of threatened frogs (Measey, 2011, Maritz, 2007) (Table 1).

We installed 30 pipe trap arrays in terrestrial habitats $\geq 300 \mathrm{~m}$ from water bodies and $\geq 500 \mathrm{~m}$ from each other, divided evenly among five vegetation types: coastal forest, degraded forest, acacia woodland, eucalyptus woodlot, and sugar cane cultivation. We placed a further six arrays in coastal forest $\leq 30 \mathrm{~m}$ from a water body and $\geq 50 \mathrm{~m}$ apart. Each array consisted of four, 60-cm-long, white PVC pipes. We inserted two pipes (one of $16 \mathrm{~mm}$ and $44 \mathrm{~mm}$ internal diameter) $10 \mathrm{~cm}$ into the ground near the base of a tree. We attached another of each diameter pipe together and affixed them vertically from their top at a height of $2 \mathrm{~m}$ up the tree trunk. Caps on the bottom of these pipes allowed retention of standing water (added at installation), and a hole drilled $15 \mathrm{~cm}$ from the bottom prevented flooding (Boughton et al., 2000). We installed 
Table 1. Vegetation-dwelling frog species expected in the area, species incidentally recorded in the area during the survey (location of observation is denoted NW=near water, $\mathrm{Tr}=$ terrestrial, $\mathrm{Tr} / \mathrm{NW}=$ terrestrial and near water), and inventory of captures in PVC pipe traps indicating array location (NW=near water, $\mathrm{Tr}=$ terrestrial), pipe diameter and location (G=ground, T=tree), Snout-urostyle length (SUL) of frog, and habitat type (AW=acacia woodland, $\mathrm{DF}=$ degraded forest, $\mathrm{F}=$ Forest).

\begin{tabular}{|c|c|c|}
\hline Frog Atlas species $^{\text {a }}$ & Incidentally recorded & Pipe trap captures \\
\hline \multicolumn{3}{|l|}{ Afrixalus delicates } \\
\hline \multirow[t]{2}{*}{ Afrixalus fornasinii } & NW & NW (44mm G pipe, SUL=35mm, F) \\
\hline & & NW (44 mm T pipe, SUL=35mm, F) \\
\hline Afrixalus spinifrons & $\operatorname{Tr}$ & $\operatorname{Tr}(44 \mathrm{~mm}$ G pipe, $S U L=23 \mathrm{~mm}, \mathrm{DF})$ \\
\hline Hyperolius argus & NW & \\
\hline Hyperolius marmoratus & NW & NW (outside of T pipe, F) \\
\hline \multicolumn{3}{|l|}{ Hyperolius poweri } \\
\hline Hyperolius pickersgilli & NW & \\
\hline Hyperolius pusillus & $\mathrm{Tr} / \mathrm{NW}$ & \\
\hline \multicolumn{3}{|l|}{ Hyperolius semidiscus } \\
\hline \multirow[t]{2}{*}{ Hyperolius tuberilinguis } & $\mathrm{Tr} / \mathrm{NW}$ & NW ( 44mm T pipe, SUL=27mm, F) \\
\hline & & $\operatorname{Tr}(44 \mathrm{~mm}$ G pipe, $\mathrm{SUL}=29 \mathrm{~mm}, \mathrm{AW})$ \\
\hline \multicolumn{3}{|l|}{ Leptopelis mossambicus } \\
\hline Leptopelis natalensis $^{\mathrm{b}}$ & $\mathrm{Tr} / \mathrm{NW}$ & \\
\hline
\end{tabular}

${ }^{\mathrm{a}}$ The South African Frog Atlas Project recorded twelve species of Leptopelis, Afrixalus, and Hyperolius in the two quarter-degree squares spanned by our study area (ADU, 2011). Nomenclature follows du Preez and Carruthers (2009) except Hyperolius poweri (see Channing et al., 2013).

${ }^{\mathrm{b}}$ L. natalensis was not captured in pipes despite occurring in the area. Worth noting, however, is that on two occasions we released incidentally caught $L$. natalensis individuals at the base of tree in which we had hung a set of pipes, and both frogs climbed the tree, went into a pipe, and remained there for some time. 
pipes on a variety of tree species (e.g. White Stinkwood, Celtis africana; Horsewood, Clausena anisata; Sweet Thorn, Acacia karroo; and Eucalyptus sp.) with circumference at breast height of $10-200 \mathrm{~cm}(\overline{\mathrm{x}}=53.7 \mathrm{~cm}, \mathrm{sd}=41.2 \mathrm{~cm})$. At five sugar cane cultivation arrays there were no trees, so all four pipes were inserted into the ground.

Pipe traps were installed progressively from February 17 to March 21, 2012 (summer/rainy season); we monitored arrays for $14-34$ days $(\bar{x}=21.7, \mathrm{sd}=7.3)$. As per agreements with landowners, arrays in cultivation and woodlots were removed after 14-15 days, while others remained for the study duration. We checked each array during daylight hours on an intermittent schedule as logistics allowed, i.e. 5-9 times per array at intervals of $1-9$ days $(\bar{x}=3.4$, $\mathrm{sd}=0.7)$. We identified and measured frogs found in traps and released them $\geq 50 \mathrm{~m}$ away. We also noted frogs observed incidentally (i.e. coincidentally or during casual searches) during the study period.

\section{RESULTS AND DISCUSSION}

We checked 36 arrays 219 times over 34 days (43 times for the six arrays near water and 176 for the 30 terrestrial arrays). We caught five frogs in pipes (Table 1), a trap success of $2.3 \%$ by array checking instances or $0.6 \%$ by pipe checking instances. One capture on the outside of a pipe was not included in calculations (Table1). Sparse captures prevented statistical analyses, but trap success appeared higher near water than away, $7 \%$ of array checking instances versus $1.1 \%$. We incidentally observed eight species (Table 1). Trapping success was lower than reported in the Americas, e.g. 79\% (Bartareau, 2004), 23\% (Myers et al., 2007), 2.5-4.3\% (Pittman et al., 2008), and 6\% (Ferreira et al., 2012) (some of these studies included recaptures). Several factors might have contributed to our low trapping success. 
(1) Pipes might not have provided attractive refugia. Frogs discriminate between refugia attributes (e.g. Boughton et al., 2000, Bartareau, 2004, Johnson et al., 2007, Johnson et al., 2008, Hoffmann et al., 2009). Many design factors have been investigated in relation to capture success (e.g. diameter, length, and colour); and while our 44mm diameter pipes appeared more effective than $16 \mathrm{~mm}$ and ground and tree pipes both worked, other trap designs could be investigated. (see Boughton et al., 2000, Bartareau, 2004, Johnson et al., 2007, Myers et al., 2007, Pittman et al., 2008, Johnson et al., 2008, Ferreira et al., 2012).

(2) Natural refugia provided by plants may have outcompeted pipes (Hoffmann et al., 2009). Dracaena aletriformis and Strelitzia nicolai are prevalent in the undergrowth, and their leaf axils provide hiding places for frogs (du Preez and Carruthers, 2009).

(3) The sampling period may have been too short for frogs to find the pipes (Myers et al., 2007), which could have compounded the effects of competition with natural refugia.

In conclusion, we caught three species in PVC pipe traps and found an additional species on the outside of a pipe, demonstrating that the technique can be used to trap African frogs of the family Hyperoliidae. However, trap success was low, and we captured species also encountered incidentally. We encourage further assessment of PVC pipe trapping for African vegetationdwelling frogs to support amphibian ecological studies. Altering trap design, using traps in areas with less abundant natural refugia, and installing traps a few months prior to sampling should be investigated to improve success. Further experiments could elucidate which trap designs work for which species. 


\section{ACKNOWLEDGEMENTS}

We thank Richards Bay Minerals, Department of Trade \& Industry, NSF GRFP, R. Guldemond, T. Lee, and A. Prins.

\section{REFERENCES}

ADU (2011) Summary Data of the Frogs of South Africa, Lesotho and Swaziland. Animal Demography Unit, Department of Zoology and Entomology, University of Cape Town.

BAILEY, L. L., SIMONS, T. R. \& POLLOCK, K. H. (2004) Estimating site occupancy and species detection probability parameters for terrestrial salamanders. Ecol. Appl., 14, 692-702.

BARTAREAU, T. M. (2004) PVC pipe diameter influcences the species and sizes of treefrogs captured in a Florida coastal oak scrub community. Herpetol. Rev., 35, 150-152.

BOUGHTON, R. G., STAIGER, J. \& FRANZ, R. (2000) Use of PVC pipe refugia as a sampling technique for hylid treefrogs. Am. Midl. Nat., 144, 168-177.

CHANNING, A. (2001) Amphibians of Central and Southern Africa, Cornell University Press, Ithaca.

CHANNING, A., HILLERS, A., LOTTERS, S., RODEL, M.-O., SCHICK, S., CONRADIE, W., RODDER, D., MERCURIO, V., WAGNER, P., DEHLING, J. M., DU PREEZ, L. H., KIELGAST, J. \& BURGER, M. (2013) Taxonomy of the super-cryptic Hyperolius nasutus group of long reed frogs of Africa (Anura: Hyperoliidae), with descriptions of six new species. Zootaxa, 3620, 301-350.

COQUI FROG WORKING GROUP (2006) Coqui Frog Control for Homeowners: Methods to Stop the Spread of Coqui Frogs in Hawai'i. University of Hawai'i at Manoa, Manoa.

DU PREEZ, L. H. \& CARRUTHERS, V. (2009) A Complete Guide to Frogs of Southern Africa, Struik Nature, Cape Town.

FARMER, A., SMITH, L., CASTLEBERRY, S. \& GIBBONS, J. W. (2009) A comparison of techniques for sampling amphibians in isolated wetlands in Georgia, USA. Appl. Herpetol., 6, 327-341. 
FERREIRA, E., ROCHA, R. G., MALVASIO, A. \& FONSECA, C. (2012) Pipe refuge occupancy by herpetofauna in the Amazonia/Cerrado ecotone. Herpetol. J., 22, 59-62.

HOFFMANN, K. E., JOHNSON, S. A. \& MCGARRITY, M. E. (2009) Interspecific variation in use of polyvinyl choride (PVC) pipe refuges by hylid treefrogs: a potential source of capture bias. Herpetol. Rev., 40, 426-426.

JOHNSON, J. R. (2005) Multi-scale investigations of Gray Treefrog movements: Patterns of migration, dispersal, and gene flow. University of Missouri, Columbia, Missouri.

JOHNSON, J. R., KNOUFT, J. H. \& SEMLITSCH, R. D. (2007) Sex and seasonal differences in the spatial terrestrial distribution of Gray Treefrog (Hyla versicolor) populations. Biol. Conserv., 140, 250-258.

JOHNSON, J. R., MAHAN, R. D. \& SEMLITSCH, R. D. (2008) Seasonal terrestrial microhabitat use by Gray Treefrogs (Hyla versicolor) in Missouri oak-hickory forests. Herpetologica, 64, 259-269.

LAURENCIO, D. \& MALONE, J. H. (2009) The amphibians and reptiles of Parque Nacional Carara, a transitional herpetofaunal assemblage in Coasta Rica. Herpetol. Conserv. Biol., 4, 120-131.

LINER, A. E., SMITH, L. L., GOLLADAY, S. W., CASTLEBERRY, S. \& GIBBONS, J. W. (2008) Amphibian distributions within three types of isolated wetlands in southwest Georgia. Am. Midl. Nat., 160, 69-81.

MARITZ, B. (2007) The distribution and abundance of herpetofauna on a quaternary aeolian dune deposit: Implications for strip mining. In: School of Animal, Plant and Environmental Sciences. University of the Witwatersrand, Johannesburg, South Africa.

MEASEY, G. J. (Ed.) (2011) Ensuring a Future for South Africa's Frogs: A Strategy for Conservation Research, South African National Biodiversity Institute, Pretoria.

MUENZ, T. K., GOLLADAY, S. W., VELLIDIS, G. \& SMITH, L. L. (2006) Stream buffer effectiveness in an agriculturally influenced area, southwestern Georgia. J. Environ. Qual., 35, 1924. 
MYERS, C. H., EIGNER, L., HARRIS, J. A., HILMAN, R., JOHNSON, M. D., KALINOWSKI, R., MUIR, J. J., REYES, M. \& TUCCI, L. E. (2007) A comparison of ground-based and tree-based polyvinyl chloride pipe refugia for capturing Pseudacris regilla in northwestern California. Northwest. Nat., 88, 147-154.

PITTMAN, S. E., JENDREK, A. L., PRICE, S. J. \& DORCAS, M. E. (2008) Habitat selection and site fidelity of Cope's Gray Treefrog (Hyla chrysoscelis) at the aquatic-terrestrial ecotone. J. Herpetol., 42, 378-385.

RICE, K. G., WADDLE, J. H., MILLER, M. W., CROCKETT, M. E., MAXXOTTI, F. J. \& PERCIVAL, H. F. (2011) Recovery of native treefrogs after removal of nonindigenous Cuban treefrogs, Osteopilus septentrionalis. Herpetologica, 67, 105-117.

TRIMBLE, M. J. \& VAN AARDE, R. J. (2010) Species inequality in scientific study. Conserv. Biol., 24, 886-890.

TRIMBLE, M. J. \& VAN AARDE, R. J. (2012) Geographical and taxonomic biases in research on biodiversity in human-modified landscapes. Ecosphere, 3, Article 119.

WILLSON, J. D. \& GIBBONS, J. W. (2010) Drift fences, coverboards, and other traps. In: Amphibian Ecology and Conservation (Ed. C. K. DODD JR.). Oxford University Press, Oxford. 